This is an Author's Accepted Manuscript of an article forthcoming for publication (2017) in CORPS

REVUE, copyright CNRS Editions, available online: http://www.cnrseditions.fr/collection/304 corps

\title{
Sexualisation of the fighter's body: Some reflections on women's mixed martial arts
}

\author{
Alex Channon, University of Brighton, UK \\ Ally Quinney, University of British Columbia, Canada \\ Anastasiya Khomutova, University of Brighton, UK \\ Christopher R Matthews, University of Brighton, UK
}

This short paper offers an exploration of the ways in which a long-standing phenomenon in sportmedia portrayals of female athletes manifests in the newly-emerging field of women's mixed martial arts (WMMA). Widely critiqued by scholars of sport media (e.g., Bruce, 2013; Kane, 2011), the sexual objectification of women in sport has long been held out as an example of the resilience of patriarchal logic within the world of sport. In brief, this argument rests on the notion that women's entry into (specifically 'masculine') sports threatens orthodox gender hierarchies, because it provides women with opportunities to embody characteristics historically associated with men. Relative to discourses of gender which prioritise men's 'natural' physical superiority, and take this as symbolic justification of men's power elsewhere, female athleticism carries potentially radical connotations (Messner, 1988; Roth \& Basow, 2004). However, sexualising female athletes undermines the challenge they might pose to dominant gender ideals, as it deflects attention away from the athletic capacities of women's bodies whilst repositioning them as passive objects of the male gaze. Validating and rewarding female athletes on the basis of their heterosexual attractiveness reasserts hierarchal gender relations both within sport (sport is 'by' and 'for' heterosexual men), as well as without (women are only valuable when they become objects of men's desire).

The historical trend here has been for athletes to be sexualised in ways which deny their sporting credentials and the (physical) power these signify. However, there is a growing tendency for athletic women's bodies to be sexualised in ways which accommodate overt heterosexual attractiveness with images of athletic action, muscularity and physical power - qualities once imagined as potent signifiers of masculinity, and thus at odds with heteronormative femininity. For instance, images celebrating muscular but 'feminine' body shapes abound on social media networks as apparent sources of 'fitness inspiration', often with slogans such as 'strong is the new skinny', 'muscles are sexy', and so on; female athletes appear in nude photoshoots in athletic poses ${ }^{1}$; and sports entertainment organisations such as World Wrestling Entertainment and the Legends (formerly Lingerie) Football League feature women wearing overtly sexualised clothing while performing in full-contact, apparently 'violent' sport (Khomutova \& Channon, 2015).

There is the possibility that such departures from the convention of eroticising women's weakness and passivity could be read as subversive of traditional power relations. Indeed, they certainly offer an alternative version of feminine sexiness to that enshrined in what Heywood and Dworkin refer to as "the erasure of individual women that the old Playboy model of sexualisation performed" (2003: 82). Yet important questions remain over how this inscription of bodies with gendered and sexualised qualities is accomplished, and what its consequences are for the positioning of bodies within hierarchal structures of meaning. The fact that sexiness might continue to play a larger part in defining the social value of female athletes' bodies than those of their male counterparts is problematic, but 
so too are the exclusionary practices that mark out the limited range of female bodies that might be so valued.

Furthermore, within a discursive context framed by neoliberal ideals, the continuing tendency for women athletes to be (selectively) sexualised in sport media has become framed as purely a function of women's own choices, obscuring the systemic forces shaping such possibilities (Toffoletti, 2016). Here, feminist notions of women's empowerment have been subsumed within consumerist discourses reducing feminist politics to individual practices of consumption and performance. It is in such a context that sexualised images can become framed as 'inspirational' material for other women to consume in order to feel 'empowered'. And while it is certainly true that individual women do and should - possess choices as to if and how to publicly frame their sexuality, they nevertheless do not choose the cultural parameters which define normative ideals of what makes a woman 'sexy'. Thus, the 'postfeminist sensibility' (Toffoletti, 2016) characterising the idea of sexiness as an empowering choice for individual women obscures the structural power arrangements that make such choices available to only a select few, yet continue to emphasise their importance for all.

Contemporary scholarship on the sexualisation of female athletes thereby raises questions around what sexualised bodies signify, but also to the discourses which normalise, legitimate, or otherwise construct value around them. In this paper, we explore a specific selection of examples wherein the bodies of prominent WMMA fighters have been sexualised, focusing on the discursive construction of what these bodies are supposed to mean, and to what ends their sexualisation is ostensibly deployed. While WMMA represents intriguing possibilities for gender-subversive performance and symbolism (Weaving, 2015), sexualised imagery has become a prevalent feature of this nascent sport's mediated portrayal; following the previously noted critiques of this phenomenon, they are thus worthy of critical scrutiny.

\section{Beauty and strength, or beauty as strength?}

In 2014, the Ultimate Fighting Championship (UFC) produced the $20^{\text {th }}$ season of its popular reality show, The Ultimate Fighter (TUF). The first season to feature an entirely female cast, TUF 20 also introduced the UFC's new women's strawweight division, doubling the space for women within MMA's most prestigious organisation. Notably, the promotional campaign for TUF 20 , centring on the theme 'Beauty and Strength', saw the UFC promoting its new athletes using blatantly sexualised imagery, alongside scenes of them performing fighting techniques (see Jennings, 2015). As noted above, constructions of heterosexually-appealing femininity which accommodate strength or athleticism run counter to conventional ideals of attractive, feminine women as being weak and passive. In this sense, the TUF 20 campaign created the appearance of a paradox, seeming to position WMMA as a departure from at least some aspects of normative gender ideals.

However, such an emphasis placed on the sexual attractiveness of the fighters actually did little to break with the long-standing tradition of presenting female athletes as 'women' first and 'athletes' second. Although their fighting ability was not hidden by this campaign, the focus on the TUF 20 competitors' looks echoes Felshin's (1974) notion of the 'female apologetic': the phenomenon whereby women in sport (or in this case, those responsible for promoting them) act to deflect accusations of gender non-conformity, thus stabilising male-female/masculine-feminine binaries in the face of apparent challenge. Furthermore, the explicit address adopted in the TUF 20 promotional videos signalled that the beauty of the fighters was presented for the enjoyment of heterosexual male viewers (e.g., "Easy on the Eyes, Hard on the Face"). As L.A. Jennings writes, this suggested that "if 
women were going to be part of mixed martial arts and the UFC, they must, as their first function, serve the male gaze" (2015: 73). The discursive prominence of 'beauty' in this context clearly positioned the bodies of WMMA fighters as objects for heterosexual male consumption.

On this basis, we posit that the discourse of beauty and strength therefore feeds the assumption that, for female fighters, beauty should be seen as strength. So long as beauty remains a criterion around which the value of the female fighter's body is judged (by an assumed male audience), then those fighters thought to be most beautiful will be at an advantage over those who are not. To exemplify this, we point to Paige VanZant, whose modest competitive record, and only one fight within the UFC at the time, did not prevent her from becoming the organisation's second female athlete (alongside Ronda Rousey) to receive a lucrative, individual sponsorship deal with sportswear manufacturer Reebok in 2015. With her subsequent fights promoted enthusiastically by the UFC and several WMMA commentators, and a role in the television show Dancing with the Stars in early 2016, VanZant's commercial success and position in the spotlight is somewhat surprising if only her competitive record is considered - but far less so when her youthful good looks are taken into account (Jennings, 2015).

This phenomenon therefore reveals a key source of inequality among fighters, which surely has implications for the development of WMMA. It is possible that, if organisations like the UFC do not resist the notion of 'beauty as strength', talented athletes who are not considered beautiful enough for the spotlight may lose out on the opportunities that effective promotion and sponsorship bring. While clearly disadvantageous to such individual fighters, this may indirectly harm overall levels of competition in the sport if it provides financial viability to only a limited number of athletes' careers.

\section{Body-positivity, neoliberal selfhood, and anti-feminism}

Such critical observations do not preclude other, apparently more positive outcomes from becoming associated with the sexualisation of fighters, though. Of particular interest here are discourses around body-positivity and the reclamation of the self; as one example of this, we take the iconic former UFC bantamweight champion, Ronda Rousey. Her second appearance on the front cover of Sports Illustrated magazine in 2016, wearing only body paint, is the latest in a string of risqué photoshoots that she has featured in since beginning her professional WMMA career. Rousey's message accompanying such appearances openly contests what she describes as unrealistic and harmful beauty ideals, claiming to celebrate a more natural and attainable vision of beauty (Marikar, 2015).

Furthermore, in attempting to reclaim and redefine what it means to have an attractive body, Rousey has elsewhere attacked women whose only value appears to be their mediated sexuality ('Do-Nothing Bitches', as she famously called them), whilst also referring to the ways in which she was bullied as a girl for not being attractive. This narrative of reclaiming a form of physical capital she was previously denied, along with advocating for a more active, present and self-authorising femininity, appears to add some sense of moral validation to Rousey's decision to pose nude. As noted above, it is suggestive of an attempt at breaking with - and in fact, openly stigmatising - visions of sexy femininity that fit Heywood and Dworkin's description of the 'Playboy' model (2003): eroticising women's weakness and their submissiveness to/dependence upon men.

The construction of such positive, self-affirming narratives certainly make straightforward critiques of coercive media 'sexploitation' difficult to sustain. But it remains important to note that this sense of control over what one's body should look like, and what meanings will be attached to it within media outputs, falls neatly in line with the neoliberal model of selfhood that has become central to 
contemporary practices of athlete sexualisation. Critical attention needs turning to the fact that women such as Rousey are able to materially and psychologically benefit from notions of a 'reclaimed self' when the terms of that self-reclamation are, coincidentally, highly amenable to the editors of Sports Illustrated magazine's swimsuit issue.

The point here is not to deny Rousey or others the right to pose nude or enjoy doing it, nor to criticise her for benefiting from $\mathrm{it}^{2}$, but rather to question a discourse which attaches moral value to practices which are inherently exclusionary, and supportive of a wider culture of normalised sexual objectification. This discursive conflation of choice, freedom and autonomy with public nudity risks reducing women's 'empowerment' to a simple matter of going along with existing patterns of commodified, heteronormative sexual performance, or not - rather than speaking up against the structural inequalities that these practices help to reinforce.

A further example can be found in a less visible place. Rousey's fellow UFC competitor, Bec Rawlings, posted an image of her near-naked body to social networking sites Instagram and Twitter in 2015, holding a placard stating, 'Fuck feminism/I believe in/human rights.../for all!!!'. Elaborating on her argument by equating the idea of sexual objectification with essentialised female weakness, and her own assumed sexual agency with strength and freedom, Rawlings' deployment of her naked body articulated a poorly-conceived criticism of feminist opposition to sexualisation. This statement exemplifies the ideological work performed by postfeminist discourse; feminism is positioned as a coercive practice which constructs women as 'weak victims', while the sexualised, powerful and 'free' body of the WMMA fighter becomes a symbol of women's agency in a world which no longer needs feminist interventions. Regardless of Rawlings' erroneous take on feminism (see Jones, 2015), the specific use of her nude form to overtly articulate anti-feminist politics further signifies the potency of WMMA fighters' bodies as sites of meaning-making in the neoliberal economy of mediated sport.

\section{Sex sells/selling sex}

Rawlings is certainly not the only WMMA competitor to have shared sexualised images on social media. Of the many who have done so, a common narrative emerges - showing some skin is considered a good way to catch the attention of fans (Wilcox, 2014). Many WMMA athletes have engaged in such self-promotion strategies, including Ronda Rousey, Meisha Tate, Felice Herrig, and others (see Fowlkes, 2012). However, Japanese fighter Rin Nakai, who debuted in the UFC in 2014, offers a particularly stark example. An undefeated (16-0) competitor in the Pancrase promotion at the time, Nakai's competitive credentials took second-stage to fascination with her fetishistic selfpromotion videos in Western MMA media before her first fight (Raimondi, 2014). These performances saw her muscular, buxom form dressed in lingerie, wrapped in a bed sheet, or outright naked, while posing suggestively on a bed, exercising in a gym, and in one clip, allowing horned beetles to crawl over her breast and arm. In explaining the videos, Nakai claimed that "people who don't have any idea about MMA watch my videos and might start to watch MMA and the UFC" (Raimondi, 2014), thus echoing the oft-cited mantra that 'sex sells', and is thus an effective way to promote women's sport.

The commercial appropriation of female fighters' sexuality is not confined to the promotion of sport itself, as several athletes have also performed in sexualised marketing campaigns for other products ${ }^{3}$. For some, such efforts have become normalised aspects of their media presence. For instance, the Russian Bellator $F C$ competitor, Anastasia Yankova, regularly posts photographs to her own Instagram account of her semi-nude body, posed in ways which clearly imitate the plethora of sexualised 'fitness inspiration' images mentioned earlier. Here, Yankova's role in marketing MMA apparel produced by 
the fight promoter White Rex is noteworthy. The slogan under which she models their clothing, 'Strength through Beauty', neatly encapsulates the problematic idea outlined above - that a female athlete's primary source of strength is her looks. Having worked as a model before competing in WMMA, Yankova is undoubtedly well-used to this notion. And, if we accept that social media provides a platform for the deliberate construction of celebrity athletes' desired public personae, and thus a mechanism for managing public relations and career trajectories (Reichart Smith \& Sanderson, 2015), we might suggest that Yankova - and others posting sexualised images with comparable frequency, such as American Felice Herrig and Australian Bec Rawlings - considers the commodification of her sexuality to be of singular importance in this respect.

While Yankova, Nakai, and the other athletes discussed here are certainly within their moral rights to do whatever they please with their bodies, we remain uncomfortable that the commodification of athletes' sexuality plays such a role in WMMA. The notion that sexualising oneself detracts from the respect one might earn as an athlete is certainly worth considering here - one need only look to the 'Lingerie Fighting Championship' for a somewhat extreme example of this principle 4 . But perhaps more importantly, the very idea that sex is an effective way to market women's sport itself deserves to be questioned. As Kane (2011) argues, sexualised marketing is ultimately in the business of selling sex, and not sport - a claim supported by empirical research suggesting that sexualised marketing can backfire among key audience demographics for women's sport (Kane \& Maxwell, 2011). Indeed, it is likely that a growth in WMMA's female fan-base could make the sexualised marketing of its fighters counter-productive, predicated as it is on an assumed heterosexual male audience. While there might be room for some debate on this point, we caution WMMA competitors and promoters against uncritically reproducing sexualised imagery as a primary means of marketing either individual athletes or the sport as a whole. While this may capture the attention of some fans and sponsors in the short term, it could risk undermining one's credibility as an athlete and/or alienating some groups of potential fans, not to mention reproducing inequalities between fighters and thus harming WMMA as a whole, as outlined above.

\section{Conclusion}

In this short paper, we have attempted to outline some of the ways in which WMMA fighters' sexualised bodies are positioned relative to discourses of gender, neoliberal selfhood, and athlete commodification. We suggest that a complex set of relationships exist between the bodies of female fighters and the wider construction of meaning within this sport. If the much-vaunted promise of WMMA as a gender-subversive practice is to be realised (see Channon \& Matthews, 2015), we argue that both individual athletes and institutional players in the sport's development need to adopt a more critical view of the rapidly-normalising phenomenon of fighters' sexualisation. Sensitivity towards the unintended consequences of marketing on the basis of sex appeal, along with critical resistance to the necessarily unfair, exclusionary nature of notions such as 'strength and/through/in beauty', will help to create a more inclusive developmental climate within WMMA. Of primary concern for any debate on this issue should be the effective promotion of WMMA athletes as athletes, in ways which can be beneficial for all women who want to be involved in, or take inspiration from, this sport. 


\section{Notes}

1 E.g., ESPN Magazine's 'body issue': http://espn.reprintmint.com/galleries/the-body-issue.html.

2 Rousey herself has no problem with women earning money for being sexualised; as she reportedly responded to the news of a pornstar parodying her under the stage name 'Ronda ArouseMe': "At least some girl somewhere is paying her bills".

3 Ronda Rousey's advert for Carl's Junior being one of the more famous examples: https://www.youtube.com/watch?v=ql2YwwTDr5w.

4 An MMA-equivalent of 'Foxy Boxing', the LFC features glamour models competing in what appear to be largely staged fights.

\section{References}

Bruce, T. (2013) Reflections on communication and sport: On women and femininities. Communication \& Sport, 1(1-2), 125-137

Channon, A. and Matthews, C.R. (eds.)(2015) Global Perspectives on Women in Combat Sports. Basingstoke: Palgrave Macmillan

Felshin, J. (1974) The triple option... for women in sport. Quest, 21(1), 36-40

Fowlkes, B. (2012) Tate looks to make challenger Rousey pay for not paying dues. Sports Illustrated. Available at: http://www.si.com/more-sports/2012/03/01/miesha-tate, accessed 6.5.16

Heywood, L. \& Dworkin, S. (2003) Built to Win: The Female Athlete as Cultural Icon. Minneapolis, MN: University of Minnesota Press

Jennings, L.A. (2015) 'Beauty and Strength': Defining the female body in The Ultimate Fighter season 20 promotional campaign. In A. Channon \& C.R. Matthews (eds.) Global Perspectives on Women in Combat Sports. Basingstoke: Palgrave Macmillan, pp.73-85

Jones, S. (2015) "Rowdy" Bec Rawlings equates oppression with weakness, denounces "feminism". Women's MMA. Available at: http://womensmma.com/ufc/rowdy-bec-rawlings-equatesoppression-with-weakness-denounces-feminism-ufc/, accessed 30.3.16

Kane, M.J. (2011) Sex sells sex, not women's sports. The Nation, 293(7), 28-29

Kane, M.J. \& Maxwell, H.D. (2011) Expanding the boundaries of sport media research: Using critical theory to explore consumer responses to representations of women's sports. Journal of Sport Management, 25(3), 202-216

Khomutova, A. \& Channon, A. (2015) 'Legends' in 'lingerie': Sexuality and athleticism in the 2013 Legends Football League US season. Sociology of Sport Journal, 32(2), $161-182$

Marikar, S. (2015) Ronda Rousey's next fight: Body image in Hollywood. New York Times. Available at: http://www.nytimes.com/2015/10/11/fashion/ronda-rouseys-next-fight-body-image-inhollywood.html, accessed 6.5.16

Messner, M. (1988) Sports and male domination: The female athlete as contested ideological terrain. Sociology of Sport Journal, 5(3), 197-211

Raimondi, M. (2014) Rin Nakai says bizarre videos were her idea to 'get more attention from the fans'. Fox Sports. Available at: http://www.foxsports.com/ufc/story/rin-nakai-says-bizarre-videos-wereher-idea-to-get-more-attention-from-the-fans-091714, accessed 30.3.16

Reichart Smith, L. \& Sanderson, J. (2015) I'm Going to Instagram it! An analysis of athlete selfpresentation on Instagram. Journal of Broadcasting \& Electronic Media, 59(2), 342-358

Roth, A. \& Basow, S. (2004) Femininity, sports, and feminism: Developing a theory of physical liberation. Journal of Sport and Social Issues, 28(3), 245-265

Toffoletti, K. (2016) Analysing media representations of sportswomen: Expanding the conceptual boundaries using a postfeminist sensibility. Sociology of Sport Journal, online first, doi: 10.1123/ssj.2015-0136 
Weaving, C. (2015) 'Chicks fighting in a cage': A philosophical critique of gender constructions in the Ultimate Fighting Championship. In A. Channon \& C.R. Matthews (eds.) Global Perspectives on Women in Combat Sports. Basingstoke: Palgrave Macmillan, pp.57-72

Wilcox, N. (2014) Can sex sell women's MMA? Miesha Tate and Rin Nakai say yes. Bloody Elbow. Available at: http://www.bloodyelbow.com/2014/9/18/6401749/can-sex-sell-womens-mmamiesha-tate-and-rin-nakai-say-yes, accessed 6.5.16 